\title{
Ultrasound-Guided Microwave Ablation of Unresectable Hepatocellular Carcinoma: Short Term Response and Predictors of Success
}

\author{
TAMER M. DAWOUD, M.Sc.*; MOHAMED M. HEFEDA, M.D.**; KHALED E. EL-SHAFEY, M.D.** and \\ TALAL A.Y. AMER, M.D.***
}

The Departments of Radiology*, Radiodiagnosis**, Faculty of Medicine, Tanta University and Radiodiagnosis Department***, Faculty of Medicine, Mansoura University

\begin{abstract}
Background: Microwave ablation (MWA) refers to all electromagnetic methods of inducing tumor destruction.

Aim of Study: The aim of this study was to evaluate the outcome of ultrasound-guided microwave ablation of unresectable hepatocellular carcinoma using cold shaft antenna.

Material and Methods: A total of 65 patients with Hepatocellular carcinboma (HCC) were referred to interventional Radiology Department for ablation of presumed non resectable tumor. The study group included $49(75.4 \%)$ male and 16 $(24.6 \%)$ female, with an average age $( \pm S \mathrm{SD})$ of $55 \pm 7.2$ years (range, 48-72 years). Conventional gray scale ultrasound and triphasic computed tomography were performed for all patients before ablation. The microwave system used was HS AMICA (apparatus for microwave ablation, hospital service, Rome, Italy), with electronically controlled microwave generator. A 14 Gauage cooled shaft electrode named AMICA-probe was used to deliver microwave power to the liver tissue. The patients were then followed-up with contrast enhanced computed tomography (CT) and serum a-fetoprotein levels.
\end{abstract}

Results: Among the 65 patients, complete ablation was achieved in 60 patients after initial treatment $(92.3 \%)$. Initial complete ablation rates in patients with nodules $<2 \mathrm{~cm}, 2$ $5 \mathrm{~cm}$, and $>5 \mathrm{~cm}$ were $100 \%, 92.1 \%$, and $85.7 \%$ respectively. The probability of achieving a complete ablation was significantly greater in patients with tumor size of $<5 \mathrm{~cm}$.

Conclusion: Sonographically guided MWA is an effective ablative method that can be applied in unresectable HCC of various sizes and different locations with reasonable safety.

Key Words: Microwave ablation - Unresectable Hepatocellular carcinoma - Thermal ablation - Ultrasound guided thermal ablation.

\section{Introduction}

HEPATOCELLULAR carcinoma is a significant health problem in Egypt, representing $11.75 \%$ of

Correspondence to: Dr. Tamer M. Dawoud,

The Department of Radiology, Faculty of Medicine,

Tanta University all digestive system malignancies and $1.68 \%$ of all malignancies in Egypt [1,2] .

Though the traditional treatment of hepatocellular carcinoma is surgical resection especially for small or isolated hepatocellular carcinoma, many patients are not suitable for surgery because of medical co-morbidities, associated advanced liver cirrhosis, or to advanced stage at time of presentation $[3,4]$.

Because of the unresectability of many cases, percutanous thermal ablation, mainly including radio-frequency ablation and microwave ablation have gained increasing attention [5] . Radiofrequency ablation has been considered the first line of treatment in small or early HCC $[6,7]$ as well as unresectable small tumors $<3 \mathrm{~cm}$ in diameter $[5,8]$. The microwave ablation has been emerged as a good alternative to radiofrequency ablation in the last decade $[\mathbf{9 , 1 0}]$.

The microwave ablation depends on high frequency electromagnetic radiation, through one or more electraomagnetic antennas inserted in the tumor, resulting in active heating, cellular death and coagulative necrosis [11,12,13]. Microwave ablation has several theoretical advantages over radio-frequency ablation, because of the broader energy deposition. The assumed advantages include higher intra-tumoral temperatures, larger ablated volumes in a shorter times, less heat sink effect and the potentiality to treat larger tumors [14-17].

The aim of this study was to evaluate the role of ultrasound-guided microwave ablation of unresectable hepatocellular carcinoma using cold shaft antenna. 


\section{Material and Methods}

\section{Patients:}

From October 2012 to July 2013, a total of 65 patients with $\mathrm{HCC}$ were referred to interventional radiology department for ablation of presumed nonresectable tumor. All cases were treated with ultrasound-guided percutaneous MWA. Only patients with single focal lesion were included in the study. The patients included in this study were not candidates for surgical resection because of poor liver function $(n=36)$, advanced age with chronic renal or cardiac disease $(n=13)$, recurrent hepatocellular carcinomas (lesions that developed after curative resection of an initial lesion) ( $\mathrm{n}=6$ patients) and patient refused surgery ( $\mathrm{n}=10$ patients). The exclusion criteria included patients with age $>80$ years, evidence of extraherpatic metastasis, evidence of vascular invasion, patients with coagulation disorders and poor or absent visualization of nodules on ultrasound.

\section{The study group:}

The study group included $49(75.4 \%)$ male and $16(24.6 \%)$ female, with an average age $( \pm S D)$ of $55 \pm 7.2$ years (range, $48-72$ years). All patients gave their written informed consent after explanation of the procedure steps, risks, benefits and alternative treatment procedures. The study was approved by the medical ethics committee of the hospital. The base line features of the study population is summarized in Table (1). The study included 26 patients (40\%) aged more than 60 years. Ascites was noted in 38 patients $(58.5 \%)$.

Table (1): Basic features of the 65 patients with hepatocellular carcinoma.

$\begin{array}{ll}\text { Gender: } & \\ \text { Male } & 49(75.4 \%) \\ \text { Female } & 16(24.6 \%) \\ \text { Age: } & 39(60 \%) \\ \quad \text { <60 years } & 26(40 \%) \\ \quad>60 \text { years } & \\ \text { Hepatitis: } & 55(84.6 \%) \\ \text { Hepatitis C } & 5(7.6 \%) \\ \text { Hepatitis B } & 3(4.6 \%) \\ \text { Hepatitis B\&C } & 2(5.4 \%) \\ \quad \text { Non } & \\ \text { Child-Pugh: } & 24(36.9 \%) \\ \text { A } & 41(63.1 \%) \\ \text { B } & \\ \text { AFP level (ng/ml): } & 11(16.9 \%) \\ \quad<20 & 47(72.3 \%) \\ \text { 20-400 } & 7(10.7 \%) \\ \quad>400 & \\ \text { CA199 level }(U / m l): & 42(64.6 \%) \\ \quad<50 & 23(35.3 \%) \\ \quad>50 & \\ \text { Type of tumor: } & 59(90.7 \%) \\ \text { First } & 6(9.2 \%) \\ \text { Recurrent } & \\ \text { Ascites: } & 38(58.5 \%) \\ \quad \text { Yes } & 27(41.5 \%) \\ \text { No } & \end{array}$

\section{Pre-treatment ultrasound:}

Conventional gray scale ultrasound was performed for all patients, using Philips HD 7 system. The aim was the assessment of the focal lesions (site, size, echogenicity, shape and number), the presence of vascular invasion, the presence of ascites, and the presence of lymph nodes. Color Doppler assessment was done for the patency of the portal vein and the hepatic veins.

\section{Pre-treatment triphasic CT:}

The aim was to confirm U/S findings, and to study the pattern of enhancement of the focal lesions and for the exclusion of extrahepatic metastases.

\section{Microwave ablation procedure:}

Under real time ultrasound guidance, microwave ablation procedure was performed for all patients. The ultrasound system was Philips HD 7 with 3.5-5 MHz probe. The ablation procedure was performed under general aneasthesia for 12 Patients and 53 patients under local anaesthesia.

The microwave system used was HS AMICA (apparatus for microwave ablation, hospital service, Rome, Italy), with electronically controlled microwave generator. Operating at $2450 \mathrm{MHz}$ and capable of outputting up to $100 \mathrm{~W}$ continuous wave. A 14 Gauage cooled shaft electrode named AMICAprobe was used to deliver microwave power to the liver tissue.

Before beginning of treatment, a detailed plan for the placement of electrodes, the power output setting, and the emission time was established. The aim of the treatment was to completely destroy the tumor, as well as the surrounding $0.5-1.0 \mathrm{~cm}$ normal appearing liver tissue.

After cleansing the skin with povidone iodine which also served as a contact medium, local anesthesia is achieved by using $10 \mathrm{ml}$ of $2 \%$ xylocaine to anesthetize the skin, subcutaneous tissue, muscles and liver capsule along the assumed track of entry. A pre-incision of the skin is done and a 16 -gauge $15 \mathrm{~cm}$ guide needle with an antenna was inserted and positioned at the designated place of the tumor under sonographic guidance, and the active tip was placed in the deepest part of the tumor, being connected to the microwave generator and the energy application was then started. For tumors adjacent to major structures such as the diaphragm, gastro intestinal tract, or gallbladder, the microwave ablation electrode was inserted into the tumor in the direction perpendicular to the adjacent structure to avoid injury. 
Power output and time emission was variable according to the site and the size of the tumor. The applications of $80 \mathrm{~W}$ for 8-10 minutes was effective for treatment of tumors $2-3 \mathrm{~cm}$ and applications of $80 \mathrm{~W}$ for $10-15$ minutes was effective for treatment of tumors $<3-5 \mathrm{~cm}$. In order to get complete ablation for tumor with diameter $>5 \mathrm{~cm}$, the electrode was introduced at the distal margin of the lesion first, and then the electrode was withdrawn every $2 \mathrm{~cm}$ to repeat the treatment. The treatment was applied until the tumors were completely covered by gasification zone under ultrasound monitoring.

During application of microwave energy, an expanding hyperechogenic area was produced which roughly judges the size of the ablation zone, i.e., necrotic zone. The necrosis length overcomes the tip of the electrode ahead by few $\mathrm{mm}(2-6 \mathrm{~mm})$ depending on power and time of the treatment while the biggest increase occurs backwards and radially as the time goes over. These changes are visible on sonographic images but diminished rapidly as soon as the microwave generator was switched "off" and completely disappeared within 8 hours. Also crepitus sensation is felt through the needle during ablation. Both the hyperechoic area and the crepitus attributed to the water vapor formation.

To prevent possible tumor seeding, the needle track was cauterized for 10 seconds when the antenna was withdrawn.

Vital signs such as blood pressure, heart rate, respiration rate, and oxygen saturation were continuously monitored during the procedure.

After care: Complete bed rest for 12 hours. Observation of pulse and blood pressure for every 30 minutes for 2 hours and then every 2 hours for 12 hours. Analgesic (Panadol 500mg 3 times/day for 5 days) to control any pain experienced after the procedure. Intravenous administration of antibiotics (Ciprofloxacin 200mg/12h) was routinely used for 3 days. Patients were discharged after a 6 hour admission when the vital signs are stable.

\section{Assessment of therapeutic efficiency:}

To evaluate the tumor response to microwave ablation therapy triphasic CT was performed 1 and 3 month after ablation and complete ablation was considered to be achieved if the images revealed that, the ablation zone was beyond the tumor borders, the margin of the ablation zone was welldefined and smooth \& no contrast enhancement was detected within or around the tumor (Figs. $1,2,3$ ). The opposite was defined as incomplete ablation (Figs. 4,5).
Patients in whom complete ablation was achieved after the treatment underwent follow-up, while patients in whom complete ablation was not achieved were scheduled for other therapies. Also, serum alpha fetoprotein was checked 1 month after the MWA procedure, and if it was abnormal, it was repeated after 3 months.

Statistical analysis: Statistical analysis was done using SSPS program (Version 20.0, IBM, Armonik, New York), under widows 7. Quantitative data were expressed as mean, standard devoiation, range and median $\mathrm{X}^{2}$ test was used to compare categorical data. OS and RFS rates were evaluated using the Kaplan-Meier method. Any of the variables were considered related to OS when $p<0.05$. Log-rank analyses were conducted by the multivariate Cox proportional hazards model. The predictors for LTP were estimated by univariate Cox proportional analysis. All statistical tests were two sided. A $p$-value less than 0.05 was considered statistically significant.

\section{Results}

Sixty-five patients with single presumed nonresectable hepatic focal lesions were included in the study, after fulfillment of informed consent and inclusion criteria.

Pre -procedural ultrasound and CT criteria of hepatic focal lesions:

Table (2) summarizes the pre-procedural ultrasound and CT criteria in the studied group. Most tumors were hypoechoic (63.0.7\%), hypervascular $(73.8 \%)$, and 19 tumors near a great vessel $(29.2 \%)$. Peripheral hallow was present in only 22 patients $(33.8 \%)$.

Most tumors included in the study showed the classical pattern of enhancement (enhancement in tehe arterial phase and washout in the delayed phase). Arterio-venous shunting was noted in seven patients $(10.7 \%)$.

\section{Response to ablation:}

Among the 65 patients, complete ablation was achieved in 60 patients after initial treatment $(92.3 \%)$. A repeat MWA was performed in 5 patients due to incomplete ablation, and complete ablation was achieved in 3 patients. Thus, a total complete ablation was achieved in 63 of 65 patients $(96.9 \%)$. The initial complete ablation rates in patients with nodules $<2 \mathrm{~cm}, 2-5 \mathrm{~cm}$, and $>5 \mathrm{~cm}$ were $100 \%, 92.1 \%$, and $85.7 \%$ respectively. The probability of achieving a complete ablation was significantly greater in patients with tumor size of $<5 \mathrm{~cm}$ (Table 3 ). 
Table (2): Ultrasound and CT criteria of 65 hepatic focal lesions.

\begin{tabular}{|c|c|c|c|}
\hline \multicolumn{4}{|c|}{ Ultrasound criteria } \\
\hline & & No. & $\%$ \\
\hline \multirow[t]{3}{*}{ Echogenicity } & Hypoechoic lesion & 41 & 63.07 \\
\hline & Hyperechoic & 8 & 12.3 \\
\hline & Hetrogenous & 16 & 24.6 \\
\hline \multirow[t]{2}{*}{ Vascularity } & Hypervascular & 48 & 73.8 \\
\hline & Hypovascular & 17 & 26.1 \\
\hline \multirow[t]{3}{*}{ Maximum tumor size } & $<2 \mathrm{~cm}$ & 13 & 20 \\
\hline & $2-5 \mathrm{~cm}$ & 38 & 58.5 \\
\hline & $>5 \mathrm{~cm}$ & 14 & 21.5 \\
\hline \multirow[t]{2}{*}{ Near major vessels } & Yes & 19 & 29.2 \\
\hline & No & 46 & 70.7 \\
\hline \multirow[t]{2}{*}{ Margin type } & Well defined & 53 & 81.5 \\
\hline & Ill defined & 12 & 18.5 \\
\hline \multirow[t]{2}{*}{ Peripheral hypoechoic halo } & Present & 22 & 33.8 \\
\hline & Abscent & 43 & 66.2 \\
\hline \multicolumn{4}{|c|}{ CT criteria } \\
\hline \multirow[t]{3}{*}{ Arterial phase } & Hypo-attenuating & & \\
\hline & Iso-attenuating & 11 & 16.9 \\
\hline & Hyper-attenuating & 54 & 83.07 \\
\hline \multirow[t]{3}{*}{ Venous phase } & Hypo-attenuating & 32 & 49.2 \\
\hline & Iso-attenuating & 26 & 40 \\
\hline & Hyper-attenuating & 7 & 10.7 \\
\hline \multirow[t]{3}{*}{ Delayed phase } & Hypo-attenuating & 57 & 87.6 \\
\hline & Iso-attenuating & 8 & 12.3 \\
\hline & Hyper-attenuating & - & \\
\hline \multirow[t]{2}{*}{ Arterio-venous shunting } & Yes & 7 & 10.7 \\
\hline & No & 58 & 89.2 \\
\hline
\end{tabular}

Table (3): Correlation between tumor size and complete initial ablation.

\begin{tabular}{lccccc}
\hline & $\begin{array}{l}2 \mathrm{~cm} \\
(13)\end{array}$ & $\begin{array}{c}2-5 \mathrm{~cm} \\
(38)\end{array}$ & $\begin{array}{c}>5 \mathrm{~cm} \\
(14)\end{array}$ & $\begin{array}{c}p \text {-value } \\
(<2 \mathrm{vs} . \\
2-5 \mathrm{~cm})\end{array}$ & $\begin{array}{c}p \text {-value } \\
(2-5 \mathrm{vs} . \\
>5 \mathrm{~cm})\end{array}$ \\
\hline $\begin{array}{l}\text { Initial } \\
\text { complete } \\
\text { ablation }\end{array}$ & $13(100 \%)$ & $35(92.1)$ & $12(85.7 \%)$ & .052 & .005 \\
\hline
\end{tabular}

Correlation between CT / ultrasound findings and response to ablation:

Table (4) shows the relationship between the different ultrasound and CT criteria. The only statistically significant criterion for predicating intitial complete ablation was the well defined versus ill defined border on ultrasound. The lesions with ill defined borders were more susceptible to incomplete initial ablation $(p=0.05)$.

\section{Serum alpha fetoprotein:}

A statistically significant reduction in the level of serum alpha-fetoprotien was noted in the studied group (Table 5). In the pre-operative screening, 7 patients had serum alpha-fetoprotein $>400 \mathrm{ng} / \mathrm{ml}$, while after 1 month the number reduced to 5 and only 2 patients had serum alpha-fetoprotein more than $400 \mathrm{ng} / \mathrm{ml}$ after 6 months.
Table (4): Correlation between different pre-procedural ultrasound / CT criteria and initial complete ablation.

\begin{tabular}{|c|c|c|c|c|}
\hline \multicolumn{4}{|c|}{ Ultrasound criteria } & \multirow{2}{*}{$\begin{array}{c}p- \\
\text { value }\end{array}$} \\
\hline & & No. & $\begin{array}{l}\text { No of completely } \\
\text { ablated tumor }\end{array}$ & \\
\hline Echogenicity & $\begin{array}{l}\text { Hypoechoic lesion } \\
\text { Hyperechoic } \\
\text { Hetrogenous }\end{array}$ & $\begin{array}{l}41 \\
8 \\
16\end{array}$ & $\begin{array}{l}39(95.1 \%) \\
7(87.5 \%) \\
14(87.5 \%)\end{array}$ & 0.87 \\
\hline Vascularity & $\begin{array}{l}\text { Hypervascular } \\
\text { Hypovascular }\end{array}$ & $\begin{array}{l}48 \\
17\end{array}$ & $\begin{array}{l}45(93.75 \% \\
15(88.23 \%)\end{array}$ & 0.62 \\
\hline $\begin{array}{l}\text { Near major } \\
\text { vessels }\end{array}$ & $\begin{array}{l}\text { Yes } \\
\text { No }\end{array}$ & $\begin{array}{l}19 \\
46\end{array}$ & $\begin{array}{l}16(84.21 \%) \\
44(91.66 \%)\end{array}$ & 0.18 \\
\hline Margin type & $\begin{array}{l}\text { Well defined } \\
\text { Ill defined }\end{array}$ & $\begin{array}{l}53 \\
12\end{array}$ & $\begin{array}{l}51(96.22 \%) \\
9(75 \%)\end{array}$ & 0.05 \\
\hline $\begin{array}{l}\text { Peripheral } \\
\text { hypoechoic } \\
\text { halo }\end{array}$ & $\begin{array}{l}\text { Present } \\
\text { Absent }\end{array}$ & $\begin{array}{l}22 \\
43\end{array}$ & $\begin{array}{l}20(90.9 \%) \\
40(93.02 \%)\end{array}$ & 0.82 \\
\hline Arterial phase & $\begin{array}{l}\quad \text { CT criteria } \\
\text { Hypo-attenuating } \\
\text { Iso-attenuating } \\
\text { Hyper-attenuating }\end{array}$ & $\begin{array}{l}11 \\
54\end{array}$ & $\begin{array}{l}10(90.9 \%) \\
50(92.5 \%)\end{array}$ & 0.87 \\
\hline Delayed phase & $\begin{array}{l}\text { Hypo-attenuating } \\
\text { Iso-attenuating } \\
\text { Hyper-attenuating }\end{array}$ & $\begin{array}{l}57 \\
8 \\
-\end{array}$ & $\begin{array}{l}53(92.9 \%) \\
7(87.5 \%)\end{array}$ & 0.75 \\
\hline $\begin{array}{l}\text { Arterio-venous } \\
\text { shunting }\end{array}$ & $\begin{array}{l}\text { Yes } \\
\text { No }\end{array}$ & $\begin{array}{l}7 \\
58\end{array}$ & $\begin{array}{l}6(85.7 \%) \\
54(93.1 \%)\end{array}$ & 0.66 \\
\hline
\end{tabular}

Table (5): Level of serum alpha-fetoprotein in the studied patients pre-operative, and one month and 6 months after the procedure.

\begin{tabular}{lcc}
\hline Alpha feto protein & No. & $\%$ \\
\hline \multicolumn{3}{c}{ Pre-operative } \\
$<20$ & 11 & 16.9 \\
$20-400$ & 47 & 72.3 \\
$>400$ & 7 & 10.7 \\
& After 1 month \\
$<20$ & 28 \\
$20-400$ & 32 & 43.07 \\
$>400$ & 5 & 49.2 \\
& After 3 months & 7.6 \\
$<20$ & 35 & 53.8 \\
$20-400$ & 28 & 43.07 \\
$>400$ & 2 & 3.07 \\
\hline$-p$-value between alpha fetoprotein after 1 month and pre-operative \\
$=0.01$. \\
$-p$-value between alpha fetoprotein after 3 month and pre-operative \\
$=0.005$.
\end{tabular}

Table (6): Complications after microwave ablation in 65 patients.

\begin{tabular}{lll}
\hline Complication & No. & $\%$ \\
\hline Pain & 32 & 49.2 \\
Skin burn & 2 & 3.07 \\
Fever & 26 & 12.3 \\
Pleural effusion & 1 & 1.5 \\
Subcapsular haematoma & 3 & 4.6 \\
Nausa / vomiting & 12 & 18.4 \\
Hypotension & 4 & 6.1 \\
Tachycardia/bradycardia & 2 & 3.07 \\
\hline
\end{tabular}




\section{Complications:}

No deaths occurred peri-procedural during the three months follow-up. All complications were minor according to Society of Interventional Radiology's (SIR) Classification System for Complications by Outcome. Minimal pleural effusion was
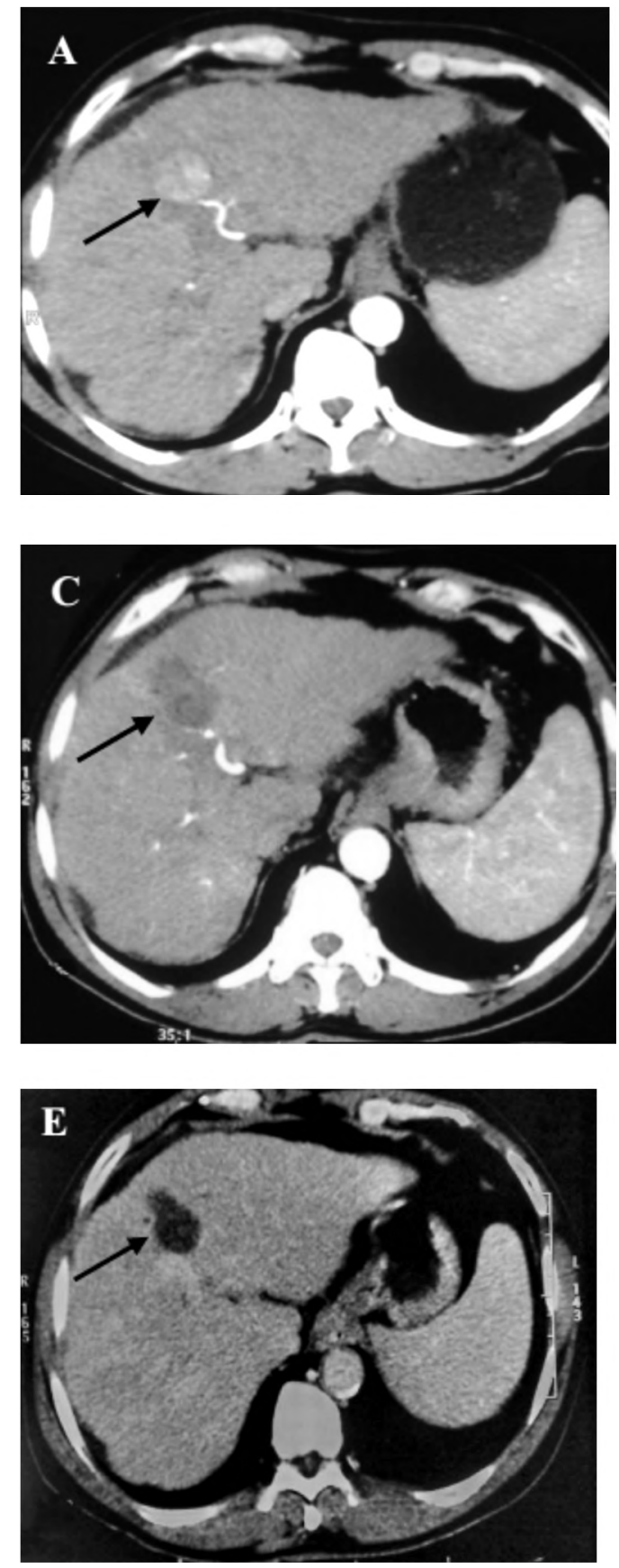

detected in one patient, requiring no treatment. Pain related to the procedure was the most common complication, observed in 32 patients, all responded to oral analgesics.

No complication requiring hospitalization was noted during the study.
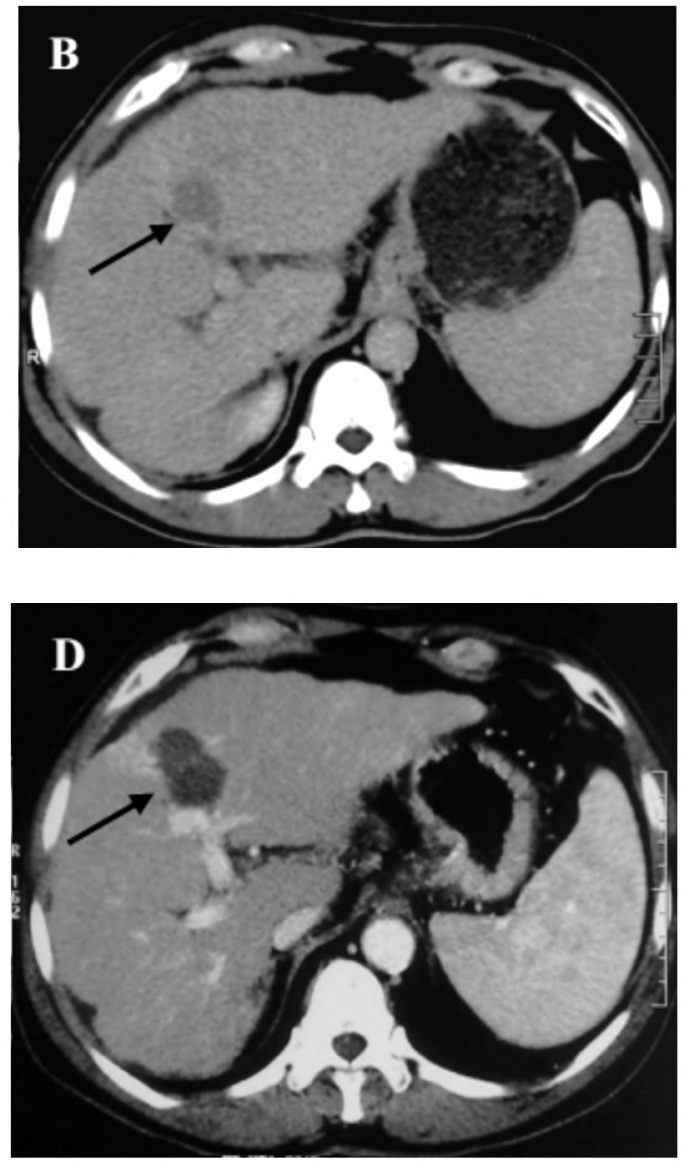

Fig. (1): Contrast-enhanced transverse CT scans in a 55-year old man with solitary HCC. $(a, b)$ Pretreatment arterial and delayed phases of triphasic contrast enhanced scan reveals a $3 \times 3$ $\mathrm{cm}$ enhancing HCC (arrow) in segment IV. (C,D,E) arterial, venous and delayed phases of triphasic CT Scan obtained 1 month after MW ablation depicts a non-enhancing hypoattenuating area (arrow head) denoting good response to therapy. 

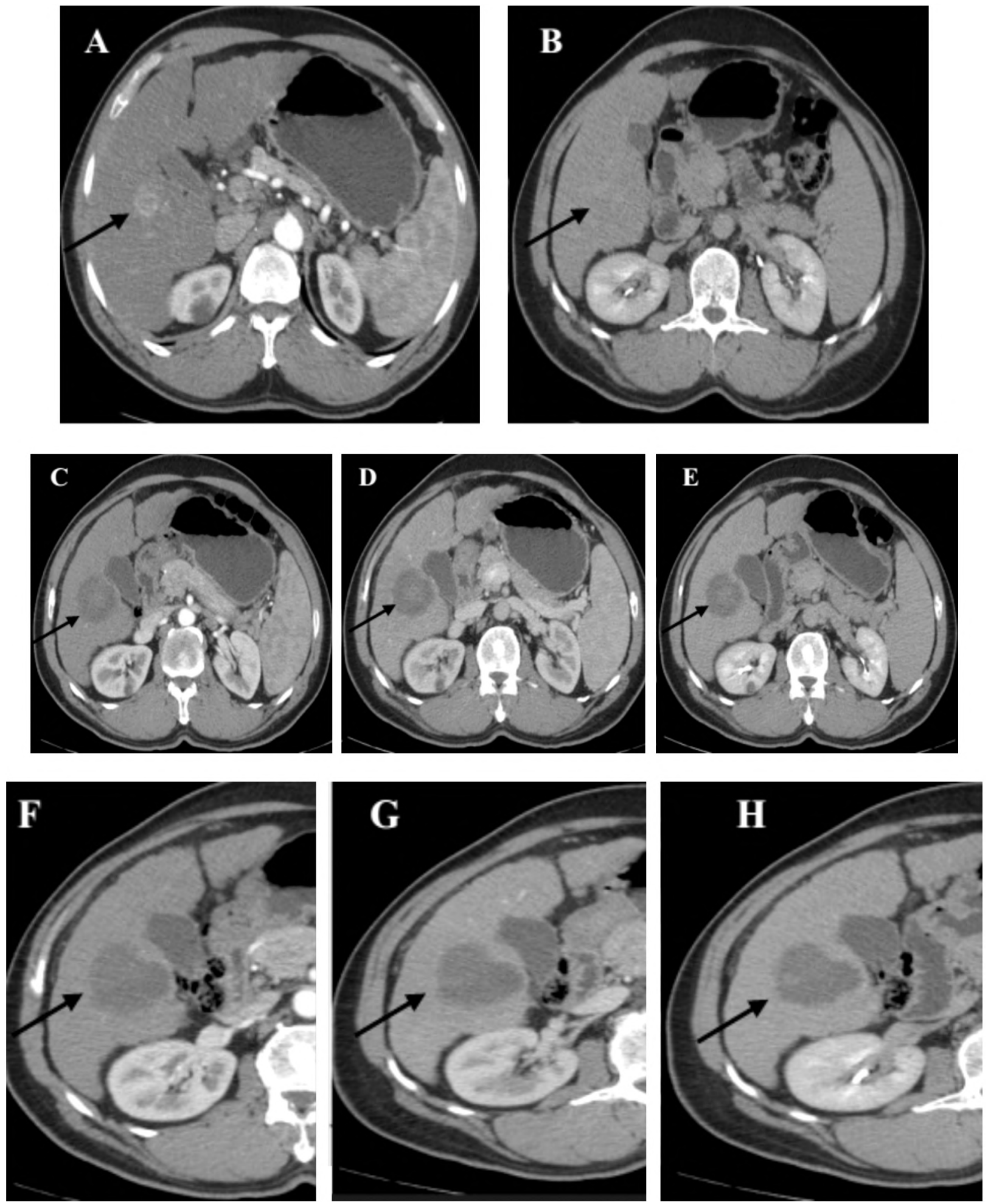

Fig. (2): Contrast-enhanced transverse CT scans in a 48-year old female with solitary HCC. (A,B) Pretreatment arterial and delayed phases of triphasic contrast enhanced scan reveals a $2 \times 2 \mathrm{~cm}$ enhancing HCC (arrow) in segment V. (C,D,E) arterial, venous and delayed phases of triphasic CT Scan obtained 1 month after MW ablation depicts a non-enhancing hypoattenuating area (arrow head) denoting good response to therapy. (F, G,H) arterial, venous and delayed phases after 3 months showing no enhancing residual / recurrent neoplastic tissue. Note the lesion is relatively near the gall bladder. 

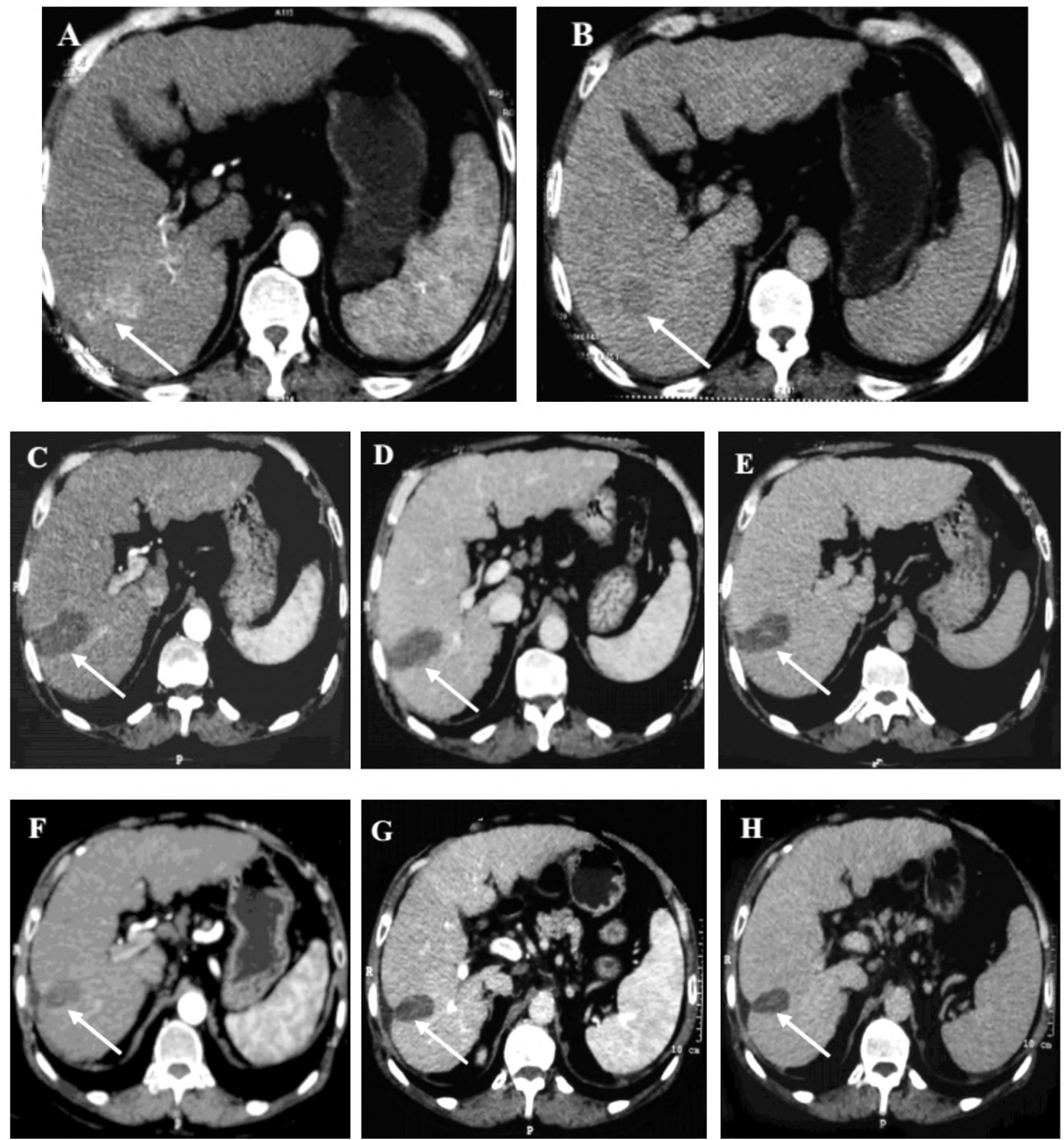

Fig. (3): Contrast-enhanced transverse CT scans in a 50-year old Male with solitary HCC. (A,B) Pretreatment arterial and delayed phases of triphasic contrast enhanced scan reveals a $2.5 \times 2 \mathrm{~cm}$ enhancing HCC (arrow) in segment VI. (C,D,E) arterial, venous and delayed phases of triphasic CT Scan obtained 1 month after MW ablation depicts a non-enhancing hypoattenuating area (arrow head) denoting good response to therapy. (F,G,H) arterial, venous and delayed phases after 3 months showing no enhancing residual / recurrent neoplastic tissue. 

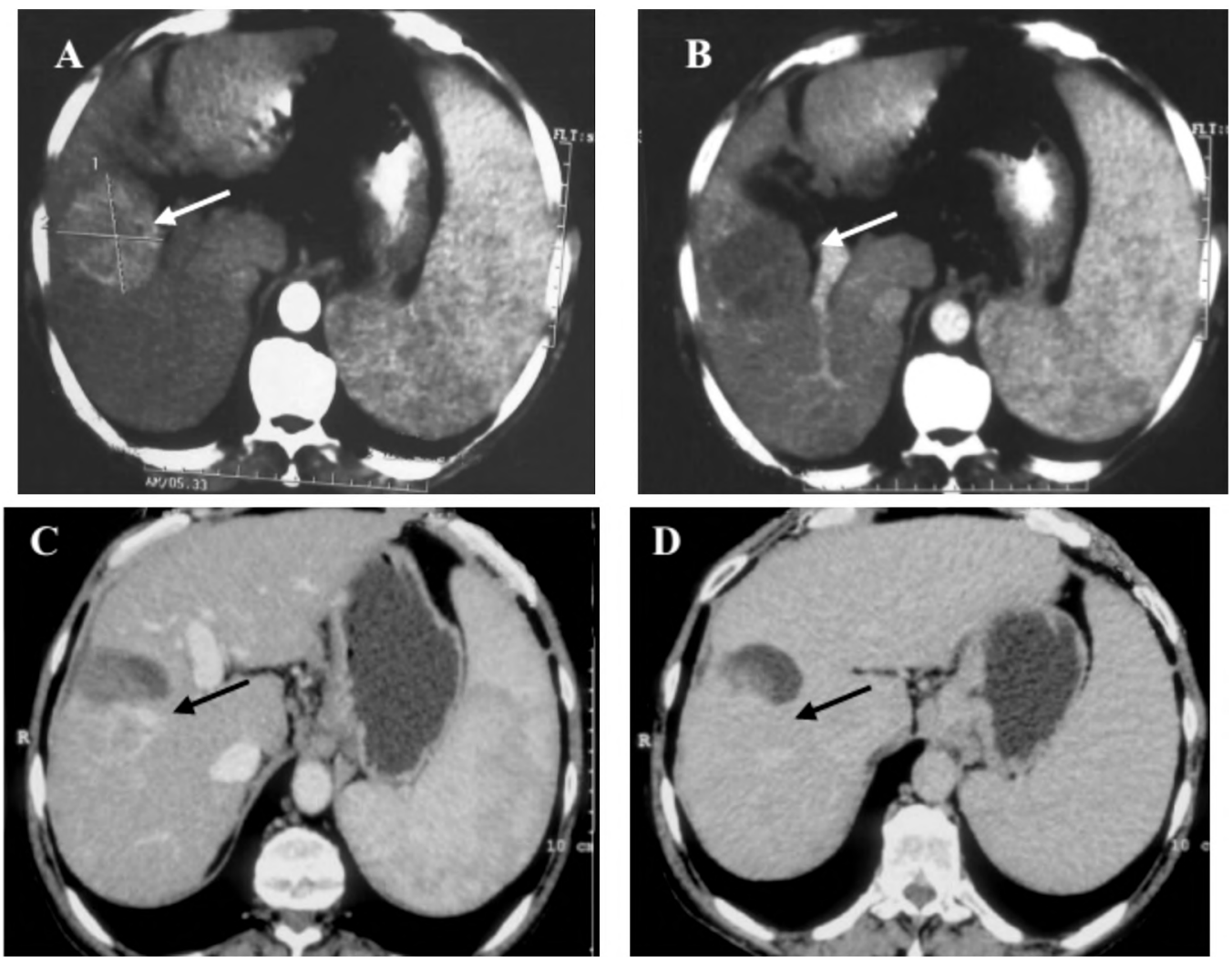

Fig. (4): Contrast-enhanced transverse CT scans in a 63-year old male with solitary HCC. (A,B) Pretreatment arterial and delayed phases of triphasic contrast enhanced scan reveals a $5.5 \times 5 \mathrm{~cm}$ enhancing HCC (arrow) in segment V. (C,D) arterial, and delayed phases of triphasic CT Scan obtained 1 month after MW ablation depicts a residual enhancing neoplastic tissue in the posterior aspect of the tumor denoting incomplete response to therapy. Note the lesion is relatively near the left portal vein.
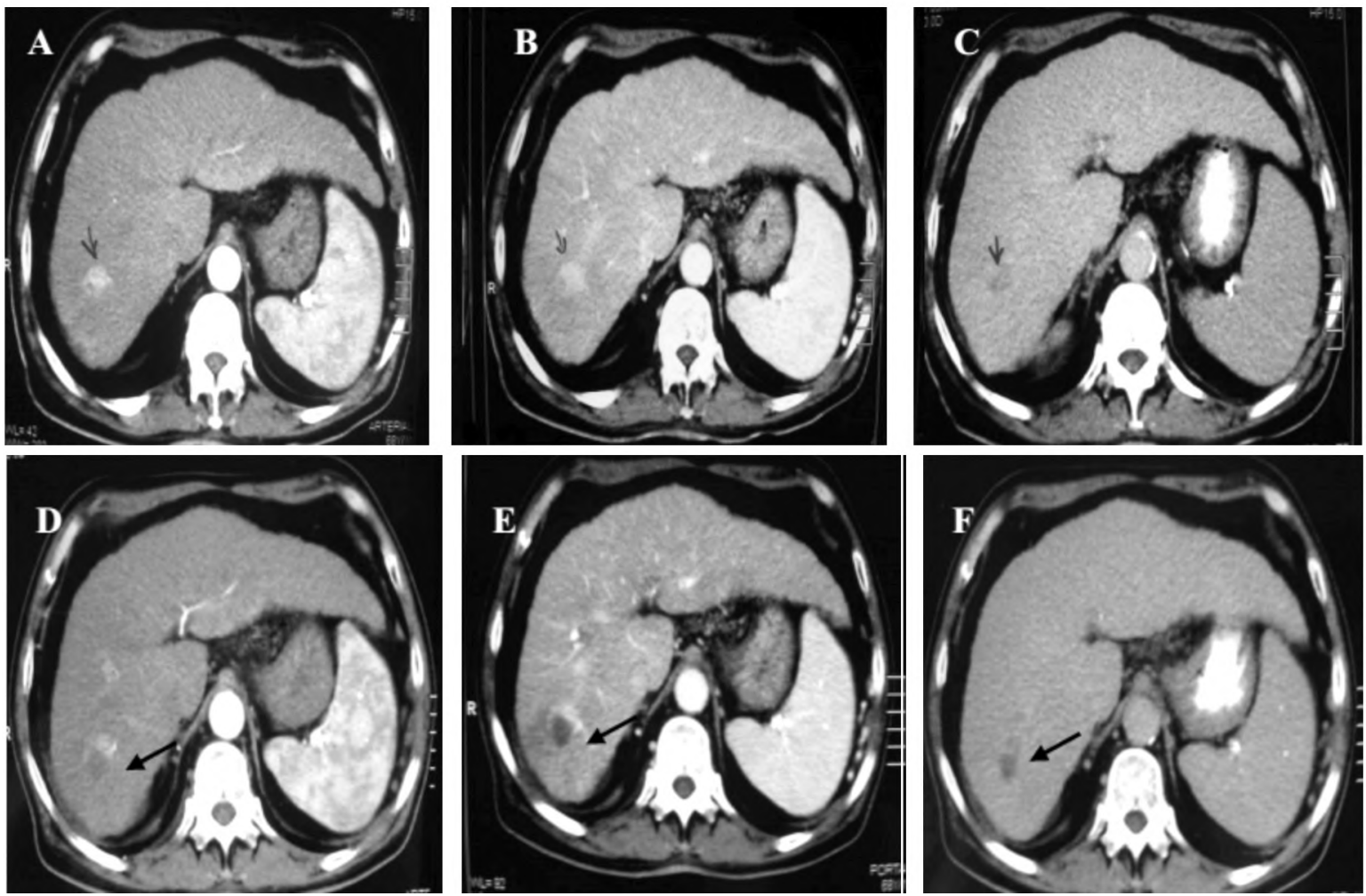

Fig. (5): Contrast-enhanced transverse CT scans in a 57-year old male with solitary HCC. (A,B,C) Pretreatment arterial, venous and delayed phases of triphasic contrast enhanced scan reveals a $3 \times 2 \mathrm{~cm}$ enhancing HCC (arrow) in segment V. (D, E,F) arterial, venous and delayed phases of triphasic CT Scan obtained 1 month after MW ablation depicts a residual enhancing neoplastic tissue in the anterior aspect of the tumor denoting incomplete response to therapy. 


\section{Discussion}

Our results shows that ultrasound guided MWA is a reasonable and successful treatment of patients with un-resectable HCC. The percentages of complete ablation of HCC compare well with previous published data.

Thermal ablation has gained great deal in management of HCC because of little invasiveness, the ability to repeat the procedure and approved therapeutic efficiency [18]. At present, radiofrequency ablation is the most commonly used thermal ablation technique and it is the first line for treatment of patients with unresectable $\mathrm{HCC}<3 \mathrm{~cm}$ [5] However, using radio-frequency ablation in tumors $>3 \mathrm{~cm}$ or near large vessels has been associated with higher recurrence rate [26]. Microwave ablation is a relatively new modality allows the generation of consistently higher intra-tumoral temperature $[20,21]$. With MWA no need to use grounding pads because the electrical current is not passing through the patient. Also, MWA is associated with decreased vulnerability to the heat sink effect, therefore lesions near by great vessels can be treated with MWA [10] . Also, multiple antennas can be used simultaneously allowing synergistic energy deposition in the treated tissue with wider ablation zones in a shorter period of time [22,23], and all these factors suggest that MWA can be used in larger tumors $[\mathbf{2 4 , 2 5 ]}$

In this study, An internally cooled-shaft antenna was used, which made it possible to expand the ablation zone, because of the ability to deliver more energy, decrease tissue charring and improve energy transfer. Also, the cooled shaft allowed longer duration treatment [26].

Our results revealed that total complete response was achieved in $92.3 \%$ of patients after the first session and $96.9 \%$ of patients by one or two sessions of MWA, which was similar to the result seen in previous studies. Alexander et al. (2015) reported technical success rate of $95.3 \%$ (61/64) [27]. Also Xu et al. (2017) reported primary local efficiency of $95.2 \%(280 / 294)$ [28]. Also Hetta et al. (2011) reported complete ablation in $96 \%$ (94/98) nodules [29]

In the current study tumor size was the single significant predictor of initial complete ablation, The success rate of nodules $<2 \mathrm{~cm}, 2-5 \mathrm{~cm}$, and $>5 \mathrm{~cm}$ were $100 \%, 92.1 \%$, and $85.7 \%$ respectively. Our results are similar to those of Ma et al. [30] with initial complete ablation rates in patients with nodules $<3,3-5$, and $5-10 \mathrm{~cm}$ were $97.9 \%$ (238/243), $94.1 \%(111 / 118)$, and $86.1 \%$ (62/72), respectively.
Also, Xu et al. [31] using multiple electrode insertion technique, attained complete ablation rates in tumors 2.0, 2.1-3.9 and $>4.0 \mathrm{~cm}$ in diameter with success rates $93.1 \%, 93.8 \%$, and $86.4 \%$, respectively.

Previous studies reported non encouraging results for MWA in treatment of tumors larger than $5 \mathrm{~cm}[14,17,32]$. On the other hand, Chen et al. [33] completely ablated 14 tumors by prolonging exposure duration and using multiple insertional schemes. Also Kuang et al. [13] well ablated 12 of 13 tumors $5.1-8 \mathrm{~cm}$. Zhang et al. [34] reported complete ablation rate for tumors $5-8 \mathrm{~cm}$ to be $85.71 \%$, similar to the results attained in the current study with successful ablation of $85.2 \%$ of tumors larger than $5 \mathrm{~cm}$. Also, Ma et al. [30] found the survival rate of patients with tumors $>5 \mathrm{~cm}$ treated with MWA to be similar to patients treated with hepatectomy of transhepatic chemo-emblization (TACE), at the same time they reported significantly higher complication rates in patients with HCC $>5 \mathrm{~cm}$ versus $\mathrm{HCC}<5 \mathrm{~cm}$, which might be attributable to the fact that ablation of larger tumors is more likely to release large amounts of bilirubin and other cellular components that may lead to hyperbilirubinemia and renal failure.

No pre-procedural ultrasound or CT criteria carried significant prediction value for the success of initial complete ablation except for the ill defined borders. Ill defined borders were more susceptible to incomplete initial ablation, with initial success rate of only $75 \%$. On the other hand, Tumors near great vessels didn't influence the success rate of ablation procedure as we successfully ablated $84.2 \%(16 / 19)$ of tumors near the great vessels. Our results are similar to the studies by Komorizono et al. [35] and Long et al. [36] which showed proximity of a tumor to great vessel did not influence the local effect on the contrary to old reports by Goldberg et al. [37] and Patterson et al. [38] . Compared with radio-frequency ablation, MW had advantages of higher thermal efficiency and less susceptibility to the heat sink effect [39], which could help to enhance the effectiveness of MW ablation for tumors adjacent to large tumors.

MW ablation is a well-tolerated technique with an acceptably low rate of major complications for treatment of malignant liver tumors [40]. A largescale study by Liang et al., over a 13-year period reported the rate of major complications is about $2.6 \%$ [10]. No major complications were reported during the current study, No complication required hospitalization or surgical management, only minor complications of which procedure related pain 
(49.2\%). The rate of minor complications has been reported as $5.7 \%-7.3 \%[\mathbf{3 3 , 1 0 ]}$. Fever is the most common side effect and more than $83.4 \%$ patients will experience fever 24-48h after MW ablation [10]. In our study, fever was reported in $40 \%$ of patients.

However, there were also some limitations existed in our study. First, the time of follow-up is not long enough. Second, most patients did not have pathological examination. The diagnosis of HCC relied on their hepatitis history and imaging examination. Third, all procedures were performed by the same team, fourth, it was a single institution study, Finally, treatment success was based on imaging follow-up only, without pathologic proof of tumor eradication, as we do not routinely perform biopsy after percutaneous ablation to assure success. Further analyses including randomized controlled trials in multi-center sites are needed.

\section{Conclusion:}

Sonographically guided MWA is a safe and effective ablative method that can be applied in unresectable $\mathrm{HCC}$ of various sizes and different locations.

\section{References}

1- MOKHTAR N., GOUDA I. and ADEL I.: Cancer pathology registry 2003-2004 and time trend analysis. In: Mokhtar N., Gouda I., Adel I., eds. Malignant digestive system tumors. Cairo: Elsheraa Press, 55-67, 2007.

2- HOLAH N.S., EL-AZAB D.S., AIAD H.A. and SWEED D.M.: Hepatocellular carcinoma in Egypt: Epidemiological and histopathological properities. Menoufisa Med. J., 28: 718-24, 2015

3- American Cancer Society. Cancer facts and figures 2013. American Cancer Society, 2011.

4- BEFELER A.S. and DIBISCEGLIE A.M.: Hepatocellular carcinoma: Diagnosis and treatment. Gastroenterology, 122: 1609-19, 2002

5- LU D.S., YU N.C., RAMAN S.S., et al.: Radiofrequency ablation of hepatocellular carcinoma: Treatment success as defined by histologic examination ofthe explanted liver. Radiology, 234: 954-60, 2005.

6- BRUIX J. and SHERMAN M.: Practice Guidelines Committee AAftSoLD: Management of hepatocellular carcinoma. Hepatology, 42: 1208-1236. doi:10.1002/hep.20933 2005.

7- CHOI D., et al.: Percutaneous radiofrequency ablation for early stage hepatocellular carcinoma as a first-line treatment: Longterm results and prognostic factors in a large single-institution series. Eur. Radiol., 17: 684-692. doi:10.1007/s00330-006v-0461-5, 2007.

8- LENCIONI R., CIONI D., CROCETTI L., et al.: Earlystage hepatocellular carcinoma in patients with cirrhosis: Long-term results of percutaneous image-guided radiofrequency ablation. Radiology, 234: 961, 2005.
9- IANNITTI D.A., MARTIN R.C., SIMON C.J., et al.: Hepatic tumor ablation with clustered microwave antennae: The US phase II trial. HPB, 9: 120-4, 2007.

10- LIANG P., WANG Y., YU X. and DONG B.: Malignant liver tumors: Treatment with percutaneous microwave ablation-complications among cohort of 1136 patients. Radiology, 251: 933-40, 2009.

11- NORTH D.A., GROESCHL R.T., SINDRAM D., et al.: Microwave ablation for hepatic malignancies: A call for standard reporting and outcomes. Am. J. Surg., 208: 28494. doi:10.1016/j. amjsurg.2014.02.002, 2014.

12- PUSCEDDU C., SOTGIA B., FELE R.M., BALLICU N. and MELIS L.: Combined microwave ablation and Cementoplasty in patients with painful bone metastases at high risk of fracture. Cardiovasc Intervent Radiol., 39:7480. doi:10.1007/s00270-015-1151-y, 2016.

13- KUANG M., LU M.D., XIE X.Y., XU H.X., MO L.Q., LIU G.J., XU Z.F., ZHENG Y.L. and LIANG J.Y.: Liver cancer: increased microwave delivery to ablation zone with cooledshaft antenn-experimental and clinical studies. Radiology, 242: 914-24, 2007.

14- LIU F.Y., YU X.L., LIANG P., WANG Y., ZHOU P. and YU J.: Comparison of percutaneous $915 \mathrm{MHz}$ microwave ablation and $2450 \mathrm{MHz}$ microwave ablation in large hepatocellular carcinoma. Int. J. Hyperthermia, 26 (5): 448-55, 2010

15- YU Z., LIU W., FAN L., SHAO J., HUANG Y. and SI $\mathrm{X}$.: The efficacy and safety of percutaneous microwave coagulation by a new microwave delivery system in large hepatocellular carcinomas: Four case studies. Int. J. Hyperther., 25: 392-8, 2009.

16- ORGAN L.W.: Electrophysiologic principles of radiofrequency lesion making. Appl. Neurophysiol., 39: 69-76, 1976.

17- SKINNER M.G., IIZUKA M.N., KOLIOS M.C. and SHERAR M.D.: A theoretical comparison of energy sources-microwave, ultrasound and laser-for interstitial thermal therapy. Phys. Med. Biol., 43: 3535-47, 1998.

18- LAU W.Y., LEUNG T.W.T., YU S.C.H. and HO S.K.W.: Percutaneous local ablative therapy for hepatocellular carcinoma. A review and look into the future. Am. Surg., 237: 171-9, 2003.

19- SOLBIATI L., IERACE T., TONOLINI M., OSTI V. and COVA L.: Radiofrequency thermal ablation of hepatic metastases. Eur. J. Ultrasound, 13: 149-58, 2001.

20- SIMON C.J., DUPUY D.E. and MAYO-SMITH W.W.: Microwave ablation: Principles and applications. RadioGraphics, 25: S69-83, 2005

21- WRIGHT A.S., SAMPSON L.A., WARNER T.F., et al.: Radiofrequency versus microwave ablation in a hepatic porcine model. Radiology, 236: 132-9, 2005.

22- WRIGHT A.S., LEE Jr. F.T. and MAHVI D.M.: Hepatic microwave ablation with multiple antennae results in synergistically larger zones of coagulation necrosis. Ann. Surg. Oncol., 10: 275-83, 2003.

23- MEREDITH K., LEE F., HENRY M.B., WARNER T. and MAHVI D.: Microwave ablation of hepatic tumors using dual-loop probes: Results of a phase I clinical trial. J. Gastrointest Surg., 9: 1354-60, 2005. 
24- SHIBATA T., IIMURO Y., YAMAMOTO Y., et al.: Small hepatocellular carcinoma: Comparison of radiofrequency ablation and percutaneous microwave coagulation therapy. Radiology, 223: 331-7, 2002.

25- YU N.C., LU D.S., RAMAN S.S., et al.: Hepatocellular carcinoma: Microwave ablation with multiple straight and loop antenna clusters-pilot comparison with pathologic findings. Radiology, 239: 269-75, 2006.

26- SHI W., LIANG P., ZHU Q., et al.: Microwave ablation: results with double $915 \mathrm{MHZ}$ antenna in ex-bovine livers. Eur. J. Radiol., 4732: 1-4, 2010.

27- ALEXANDER E.S., WOLF F.J., MACHAN J.T., CHARPENTIER K.P., BELAND M.D., IANNUCCILLI J.D., HAAS R.H. and DUPUY D.E.: Microwave ablation of focal hepatic malignancies regardless of size: A 9-year retrospective study of 64 patients. Eur. J. Radiol., 84: 1083-1090, 2015

28- XU Y., SHEN Q., LIU P., XU Z., WU P., LU Z., CHEN Y., HUANG B. and QIAN G.: Microwave ablation for the treatment of hepatocellular carcinoma that met upto-seven criteria: Feasibility, local efficacy and long-term outcomes. Eur. Radiol., 27: 3877-3887, 2017.

29- HETTA O.M., SHEBRYA N.H. and AMIN S.K.: Ultrasound-guided microwave ablation of hepatocellular carcinoma: Initial institutional experience. The Egyptian Journal of Radiology and Nuclear Medicine, 42: 343349, 2011.

30- MA I., DING M., LI J., et al.: Ultrasound guided percutaneous microwave ablation for hepatocellular carcinoma: Clinical outcomes and prognostic factors S. J. Cancer Res. Clin. Oncol., 143: 131-142, 2017.

31- XU H.X., XIE X.Y., LU M.D., et al.: Ultrasound-guided percutaneous thermal ablation of hepatocellular carcinoma using microwave and radio-frequency ablation. Clin. Radiol., 59: 53-61, 2004.

32- LU M.D., CHEN J.W., XIE X.Y., LIU L., HUANG X.Q., LIANG L.J. and HUANG J.F.: Hepatocellular carcinoma: US-guided percutaneous microwave coagulation therapy. Radiology, 221: 167-72, 2001.
33- CHEN J.W., LU M.D., XIE X.Y., LIANG L.J. and HUANG J.F.: Study on improving the techniques of microwave coagulation in treatment of patients with large liver cancer. Chin. J. Cancer, 20 (6): 1000-467, 2001.

34- ZHANG N.N., LU W., CHENG X.J., LIU J.Y., ZHOU Y.H. and LI F.: High powered microwave ablation of larger hepatocellular carcinoma: Evaluation of recurrence rate and factors related to recurrence. Clin. Radiol., 70: 1237-1243, 2015.

35- KOMORIZONO Y., OKETANI M., SAKO K., YAMASAKI N., SHIBATOU T., MAEDA M., KOHARA K., SHIGENOBU S., ISHIBASHI K. and ARIMA T.: Risk factors for local recurrence of small hepatocellular carcinoma tumors after a single session, single application of percutaneous radiofrequency ablation. Cancer, 97: 125362, 2003.

36- LONG J.Y., LI J., CAO J., HUANG L., ZHANG X.H., LIU J.K. and YAN Y.Q.: Predictive factors for the success of "one-off" ablation in single hepatocellular carcinoma patients who underwent percutaneous radiofrequency ablation. Hepatoma Res., 2: 47-52, 2016.

37- GOLDBERG S.N., HAHN P.F., HALPERN E.F., FOGLE R.M. and GAZELLE G.S.: Radiofrequency tissue ablation: Effect of pharmacologic modulation of blood flow on coagulation diameter. Radiology, 209: 761-7, 1998.

38- PATTERSON E.J., SCUDAMORE C.H., OWEN D.A., NAGY A.G. and BUCZKOWSKI A.K.: Radiofrequency ablation of porcine liver in vivo: Effects of blood flow and treatment time on lesion size. Ann. Surg., 227: 55965, 1998.

39- LIANG P., YU J., LU M.D., DONG B.W., YU X.L., ZHOU X.D., HU B., XIE M.X., CHENG W., HE W., JIA J.W. and LU G.R.: Practice guidelines for ultrasound-guided percutaneous microwave ablation for hepatic malignancy. World J. Gastroenterol., 7 (19): 5430-8, 2013.

40- LAHAT E., ESHKENAZY R., ZENDEL A., et al.: Complications after percutaneous ablation of liver tumors: A systematic review. Hepatobiliary Surg. Nutr., 3 (5): 317 323, 2014. 


\section{الاجتثاث بالميكروويف الموجة بالموجات فوق الصوتية لسرطان الكبد السبد

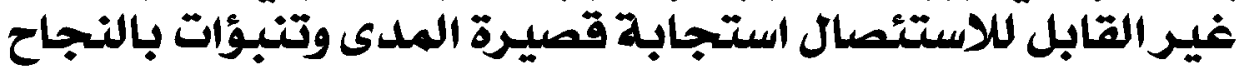

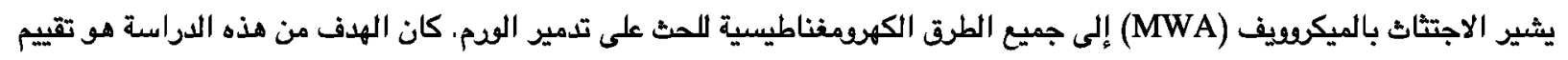
نتائج الاجتاث بالموجات فوق الصوتية الموجهة بالموجات فوق الصوتية من سرطان الكبد غير القابل اللعلاج الجراحى.

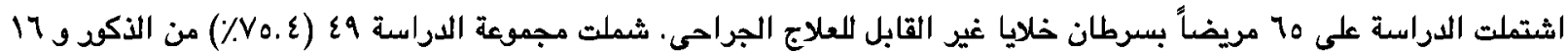

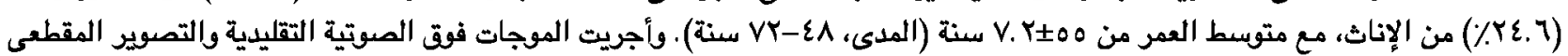

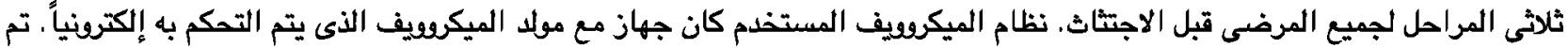

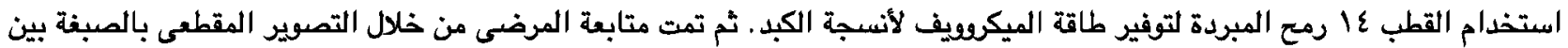

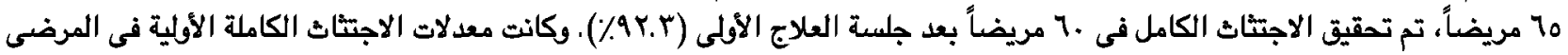

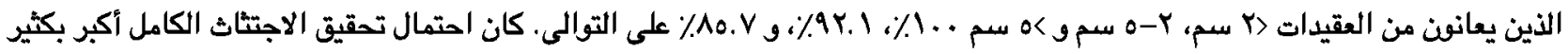
فى المرضى الذين يعانون من حجم الوم أقل من ه سم. سم. تُعد الاجتثاث بالميكرويف الموجهة إلكترونياً طريقة تجلى فعالة يمكن تطبيقها فى من سرطان الكبد غير القابل للعلاج الجراحى هع أمان 